\title{
Survival Rate and Feed Conversion Ratio of Milkfish in Different Silvoaquaculture Ponds
}

\author{
Muarif $^{1 *}$, Y. Wahyudin ${ }^{1,2}$, D. Merdekawati ${ }^{1,3}$, Mulyana $^{1}$, and F.S. Mumpuni ${ }^{1}$ \\ ${ }^{1}$ Department of Aquaculture, Faculty of Agriculture, Universitas Djuanda Bogor, Indonesia \\ ${ }^{2}$ Center for Coastal and Marine Resources Studies, IPB University, Indonesia \\ ${ }^{3}$ Department of Agribussines Fisheries and Marine, Politeknik Negeri Sambas, Indonesia \\ ${ }^{*}$ Corresponding author. Email: muarif.faperta@unida.ac.id
}

\begin{abstract}
Silvoaquaculture is a model of brackish water ponds that combines aquaculture with mangrove conservation. This study examines aspects of feed conversion ratio (FCR) and survival rate (SR) as benchmarks for milkfish production that are maintained in three different types of silvoaquaculture ponds (Empang Parit, Komplangan, and Kao-kao Ponds). This research was conducted in Indramayu Residence (Indonesia). Data collected by questionnaires and determination of the respondents was done by purposive sampling with the aim of getting fish farmers in silvoaquaculture ponds. Data analysis uses a statistical test approach (ANOVA and DMRT). The milkfish that are cultivated in silvoaquaculture ponds have a survival rate ranging from $25.00 \%-80.00 \%$ with an average of $52.98 \%$. Survival rate between types of silvoaquaculture ponds was different; Empang Parit ponds produce the lowest survival rate (average $=44.98 \%$ ) and Kao-kao ponds have the highest survival rate (average $=59.64 \%$ ). Mangroves become predatory animal habitats, so milkfish survival in silvoaquaculture ponds is low. The best feed conversion ratio of a Kao-kao pond is 1.63, followed by a Empang Parit of 1.82, and a Komplangan of 1.92. Feed conversion ratio between types of silvoaquaculture ponds was not significantly different. Mangrove ecosystems contribute to high nutrient waters, so natural food grows well and becomes additional feed for milkfish.
\end{abstract}

Keywords: Feed Conversion Ratio (FCR), mangroves, milkfish, pond, silvoaquaculture, survival rate (SR)

\section{INTRODUCTION}

One of the productive economic activity and supporting the well-being of coastal communities in Indonesia is cultivating fish in brackish water ponds [1]. FAO states that Indonesia is a producer of finfish (dominant milkfish) from the highest marine and coastal culture in the world, with a production of 864.1 thousand tons [2]. KKP (2018) reported that the milkfish commodity holds the highest production of brackish water pond production in Indonesia. In 2017 milkfish production decreased by $16.34 \%$ [3]. The production of milkfish must continue to be increased to maintain Indonesia's position in the international fish market and ensure better welfare for the community.

The problem faced in the development of milkfish culture is the aspect of environmental sustainability [4]. Milkfish cultivation has converted mangroves into ponds [5] [6], resulting in mangrove damage. Mangrove habitat that provides a high nutrient cycle [5] makes coastal communities use it for aquaculture ponds. Mangrove land clearing for ponds also continues because of the high economic value of fish from ponds [1].
Mangrove area in Indonesia is estimated to have decreased by $40 \%$ [7]. Further mangrove damage must be prevented and mangrove sustainability must be maintained. Mangrove ecosystems have an important role in providing food, protecting beaches, preventing erosion, and maintaining climate change, marine resources and productive and sustainable fisheries [8], so that the existence of mangroves must be maintained and protected from damage [9].

The challenge that must be realized in the development of milkfish production is how to develop productive ponds and maintain mangrove conservation consistently. Integration between conservation of mangroves and ponds in the form of silvoaquaculture (silvofishery or wanamina) [10] becomes a mutually beneficial solution between mangrove conservation and aquaculture [11].

Indramayu Regency is one of the locations in Indonesia where milkfish cultivation is carried out on silvoaquaculture ponds [12]. Land arises and some of the coastal ponds in this district have been planted with mangroves as an effort to preserve the environment and their waters are planted with milkfish in their waters to improve the welfare of the community. There are three 
types of silvoaquaculture ponds, namely Empang Parit, Komplangan, and Kao-kao.

Silvoaquaculture as an environmentally friendly aquaculture system that supports development sustainable must be widely developed in many areas. Information about the productivity of silvoaquaculture ponds is important to attract fish farmers to develop it. This study examines aspects of feed conversion ratio (FCR) and survival rate (SR) as benchmarks for milkfish production that are maintained in three different types of silvoaquaculture ponds. The results of this study illustrate the productivity of each type of silvoaquaculture pond which can be useful information in developing silvoaquaculture ponds for milkfish farming..

\section{METHODS}

\subsection{Data Collection}

This research was conducted in Indramayu Residence (Karangsong, Brondong, and Pabean Ilir villages). Data collected by questionnaires. Determination of the respondents was done by purposive sampling with the aim of getting fish farmers in silvoaquaculture ponds (Empang Parit, Komplangan, and Kao-kao). Data collected includes seed stocking; seed biomass, feed, fish number and biomass production.

\subsection{Data Processes}

Questionnaire data came from 100 respondents. In the initial stage the data is screened by looking at the consistency and correctness of the information provided by respondents. Questionnaires with very distorted and / or incomplete data are not used as research data. The research data were grouped according to silvoaquaculture pond types, namely Empang Parit, Komplangan, and Kao-kao ponds. The formula for calculating feed conversion ratio [13] and survival rate [14] is as follows:

$$
F C R=\frac{F}{W}
$$

With

FCR $=$ Feed Conversion Ratio

$\mathrm{F} \quad=$ Amount feed fed $(\mathrm{kg})$

$\mathrm{W} \quad=$ Weight gain $(\mathrm{kg})$

$$
S R=\frac{N t}{N o} \times 100 \%
$$

With

SR = Survival Rate $(\%)$

$\mathrm{Nt}=$ Number of individuals alive at end of time period

No $=$ Number of individuals alive at start of time period.

\subsection{Data Analysis}

Data analysis uses a statistical test approach. First the researchers conducted a data normality test. The second stage the researchers conducted a transformation of data (archi) for data that spread abnormally. In the third stage the researchers analyzed the data using analysis of variance (ANOVA). The last stage the researchers analyzed further tests using the DMRT (Duncan Multiple Range Test) on data based on ANOVA results were significantly different.

\section{RESULTS AND DISCUSSION}

\subsection{Survival Rate}

The survival rate shows the percentage of the number of fish that live to the end of the maintenance period compared to the number of seeds stocked at the beginning of the maintenance period. The milkfish that are cultivated in silvoaquaculture ponds have a survival rate ranging from $25.00 \%-80.00 \%$ with an average of $52.98 \%$. This survival rate is lower than the average survival rate of milkfish in non-silvoaquaculture ponds which is $63.3 \%$ [15] and 56.62\% - 60.82\% [16].

Empang Parit type ponds produce the lowest survival rate (average $=44.98 \%$ ), while Kao-kao type ponds have the highest survival rate (average $=59.64 \%$ ). Statistical test results show that there is a significantly difference between the survival rate of milkfish that are maintained in ponds with Empang Parit and Kao-kao types (Table 1).

Survival rate is affected by stocking densities [17], water quality [18], pathogenic bacteria [19], feed [20], pests (predators), and disease [18] [21]. The difference in survival rate between types of ponds is caused by predatory activity by predators. Empang Parit types have thick mangroves in the middle of ponds, and live various types of animals such as birds, snakes, monitor lizards, and other animals [22], which are predatory for fish (Shilman 2012). The presence of high predators in mangroves in Empang Parit causes high mortality of fish which means a low survival rate. Kao-kao types has a few mangroves and far from the beach, so it is relatively protected from predators.

Table 1. Survival rate of milkfish in silvoaquaculture ponds

\begin{tabular}{|l|c|c|l|l|}
\hline \multirow{2}{*}{ Type of Pond } & \multicolumn{4}{|l|}{ Survival rate (SR) $(\%)$} \\
\cline { 2 - 5 } & Average & Std.Dev & Min & Max \\
\hline Empang Parit & $44.98^{\mathrm{a}}$ & 18.52 & 25.00 & 75.00 \\
\hline Komplangan & $52.42^{\mathrm{ab}}$ & 13.11 & 31.64 & 73.33 \\
\hline Kao-kao & $59.64^{\mathrm{b}}$ & 12.12 & 42.86 & 80.00 \\
\hline
\end{tabular}

Note: Different superscripts show different types of farms 
The presence of predators in silvoaquaculture ponds also influences the low survival rate of milkfish when compared to the survival rate of milkfish in nonsilvoaquaculture ponds. Pond management (feeding, media sanitation, water quality management, pest and disease control, etc.) that have not yet fulfilled good fish culture also causes lower survival rate of silvoaquaculture ponds.

\subsection{Food Conversion Ratio (FCR)}

Feed conversion ratio is the amount of feed to produce $1 \mathrm{~kg}$ of fish meat, illustrating the ability of fish to convert feed into meat. FCR is calculated by comparing the total feed with the growth of fish biomass during the maintenance period. The FCR value is used to determine the feasibility of fish culture production, including the economic value feasibility. Feed costs can reach $70 \%$ of aquaculture production costs [23], so efforts to reduce FCR can reduce production costs and ensure the sustainability of aquaculture.

FCR is a key indicator of the efficiency of feed use [24]. Low feed conversion ratio indicates efficient use of feed during fish rearing. Feed conversion ratio and feed efficiency are closely related to digestibility. The greater the digestibility value of a feed, the more nutrients in the feed are used for fish growth [25]. Biotechnical factors such as feed quality [26] [27], feeding frequency [28], genetic, fish physiology [27], fish health [29] [27], and water quality [30] affect feed consumption, feed efficiency, and FCR .

Table 2. Feed conversion ratio of milkfish in silvoaquaculture ponds

\begin{tabular}{|l|c|c|c|c|}
\hline \multirow{2}{*}{ Type of Pond } & \multicolumn{4}{|c|}{ Feed conversion ratio (FCR) } \\
\cline { 2 - 5 } & Average & Std.Dev & Min & Max \\
\hline Empang Parit & 1.82 & 0.78 & 0.51 & 3.17 \\
\hline Komplangan & 1.92 & 0.84 & 0.90 & 3.44 \\
\hline Kao-kao & 1.63 & 0.92 & 0.72 & 3.70 \\
\hline
\end{tabular}

The results of statistical tests show that in the three types of silvoaquaculture farms there were not significantly different in the feed conversion ratio. The best feed conversion ratio of a Kao-kao pond is 1.63, followed by a Empang Parit of 1.82, and a Komplangan of 1.92. The value of this feed conversion ratio is still not good when compared to Malik's (2010) research, which is 1.15 [31], and Chilmawati's research (2018) is $1.52-1.61$ [32], however the FCR of fish normally ranges from 1,02,4 [33] or 1,00-2.86 [23]. High mortality will result in high FCR [34]. Feed conversion ratio value will be determined by the feed quality, including the level of protein energy [26]

The size of the biotechnical aspects that can affect FCR are feed quality, feeding rate and feeding frequency. Good feeding is feed that is as needed (Rosmawati et al.
2019), nutritious, on time and in the right dosage (Mulyana and Rosmawati (2019) so as to produce optimal growth. Feed quality and feeding frequency (twice a day) are relatively the same at all types of ponds, the smallest percentage of feeding in Empang Parit type is 1.97-4.93\% with an average of $2.86 \%$, while in Komplangan and Kaokao ponds is $1.97-7.88 \%$ with average of $3.55 \%$ and $3.40 \%$ Feeding rate is lower than the feeding rate used by Malik's research (2010) which is 3-5\%. The results of statistical analysis there is no correlation between feeding and growth of milkfish biomass that is maintained in Empang Parit and Kao-kao types, whereas in Komplangan ponds there is a positive relationship between feeding and growth of biomass. Poor feed management can lead to high FCR. Ineffective feeding techniques (blocked by mangroves) in the Komplangan pond causes uneven distribution of feed resulting in low feed consumption. Remaining wasted food causes accumulation of ammonia and $\mathrm{H}_{2} \mathrm{~S}$ which results in poor water quality and can reduce fish appetite.

Aquaculture on silvoaquaculture ponds applying the traditional pattern leads to semi-intensive, supplementary feeding is carried out in limited quantities [35]. Additional feed is obtained from plankton that grows in ponds [36] and is a natural food for milkfish. Nutrientrich mangroves contribute nutrients to pond waters so that plankton (natural food) grows well [37]. The existence of natural food in silvoaquaculture ponds is quite available, so that by feeding $1.97 \%$ it is also able to support production.

\section{CONCLUSION}

Survival rate between different types of silvoaquaculture ponds and the Kao-kao type has the highest survival rate and Empang Parit ponds produce the lowest survival rate. Mangroves become predatory animal habitats, so milkfish survival in silvoaquaculture ponds is low. Feed conversion ratio between types of silvoaquaculture ponds was not significantly different. Mangrove ecosystems contribute to high nutrient waters, so natural food grows well and becomes additional feed for milkfish.

\section{ACKNOWLEDGMENT}

The authors would like to thank the Ministry of Research and Technology for funding this research (PTUPT Research Program), to Indramayu Regency's Fisheries and Marine State, LPPM and the Department of Fisheries, Djuanda University, Bogor for support projects.

\section{REFERENCES}

[1] N. Fira, "Analisis ekonomi konversi lahan mangrove menjadi lahan tambak Kecamatan Labakkang Kabupaten Pangkep," Universitas Hasanuddin, Makassar, 2017. 
[2] FAO, The State of World Fisheries and Aquaculture 2018. Rome: FAO, 2018.

[3] KKP, Kelautan dan perikanan dalam angka tahun 2018. Jakarta: Kementerian Kelautan dan Perikanan (KKP), 2018.

[4] M. . Adewolu, S. L. Akintola, A. Jimoh, F. Owodehinde, O. Whenu, and K. Fakoya, "Environmental threats to the development of aquaculture in Lagos State, Nigeria," Eur. J. Sci. Res., vol. 34, no. 3, pp. 337-347, 2009.

[5] UNEP, The importance of mangroves to people: a call to action, Van Bochov. Cambridge.: United Nations Environment Programme World Conservation Monitoring Centre, 2014.

[6] Ishak and I. A. Saputra, "Pengaruh aktivitas penduduk terhadap kerusakan hutan mangrove di Desa Lalombi Kecamatan Banawa Selatan," J. GeoTadulako, vol. 3, no. 6, pp. 52-63, 2015.

[7] D. Murdiyarso et al., "The potential of Indonesian mangrove forests for global climate change mitigation," Nat. Clim. Chang., vol. 5, no. 2015, pp. 1089-1092, 2015.

[8] Muarif, "Karakteristik Ekosistem Mangrove di Kawasan Pesisir Kepulauan Natuna," J. Mina Sains, vol. 3, no. 2, pp. 44-49, 2017.

[9] Muarif, A. Damar, S. Hariyadi, M. Boer, and D. Sutrisno, "Tingkat kepekaan mangrove Indonesia terhadap tumpahan minyak," J. Mns. dan Lingkung., vol. 23, no. 3, pp. 374-380, 2016.

[10] W. J. Fitzgerald, "Silvofisheries: Integrated Mangrove Forest Aquaculture Systems," in Ecological aquaculture: the evolution of the llue revolution, Oxford: Blackwell Science Ltd, 2002, pp. 161-262.

[11] R. H. Bosma, T. H. Nguyen, A. J. Siahainenia, H. T. P. Tran, and H. N. Tran, "Shrimp-based livelihoods in mangrove silvo-aquaculture farming systems," Rev. Aquac., vol. 8, no. 2016, pp. 4360, 2016

[12] Muarif, Y. Wahyudin, and D. Merdekawati, "Water quality at silvoaquaculture pond in indramayu regency," IOP Conf. Ser. Earth Environ. Sci., vol. 383, no. 2019, p. 012033, 2019.

[13] G. L. Jensen, Handbook for common calculations in finfish aquaculture. Louisiana: Louisiana State University Agricultural Center, 1988.

[14] C. J. Krebs, Ecological Methodology. Menlo Park: Benjamin Cummings, 2014.

[15] N. Baiduri, N. R. Alitrah, B. S. Tumangger, Fitriani, and B. Al Fajar, "Level Mortalitas Chanos chanos terhadap Pemberian Pakan Artemia dengan Penambahan Vitamin C, " J. Jeumpa, vol. 5, no. 1, pp. 28-33, 2018.

[16] B. Pantjara and E. A. Hendradjat, "Produksi bandeng (Chanos chanos) melalui aplikasi pupuk organik," J. Ris. Akuakultur, vol. 6, no. 2, pp. 253-262, 2011.
[17] N. Ronald, B. Gladys, and E. Gasper, "The effects of stocking density on the growth and survival of nile tilapia (Oreochromis niloticus) fry at son fish farm, Uganda," J. Aquac. Res. Dev., vol. 5, no. 2, pp. 1-7, 2014.

[18] Rosmawati and Muarif, "Growth and Feed Efficiency of Gourami Fish Reared in Biofloc Media with Different C / N Ratios," Int. J. Sci. Basic Aplpied Res., vol. 36, no. 6, pp. 47-59, 2017.

[19] R. Wijayanti, Muarif, and D. Lesmana, "Tingkat kelangsungan hidup dan rasio konversi pakan pada budidaya ikan gurami (Osphronemus goramy LAC.) dengan sistem bioflok dan pemberian pakan kadar protein yang berbeda," J. Mina Sains, vol. 5, no. 1, pp. 42-49, 2019.

[20] N. Nazhiroh, Mulyana, and F. S. Mumpuni, "Pengaruh penambahan tepung Spirulina platensis dalam pakan terhadap pertumbuhan dan efisiensi pakan ikan mas koki (Carassius auratus)," J. Mina Sains, vol. 5, no. 1, pp. 50-57, 2019.

[21] M. A. Dzakiy, A. Buchori, F. Nurdyansyah, R. Istiyaningsih, and V. Nindita, "Pembuatan desain kolam ikan bandeng berbasis konsep biosecurity bagi masyarakat petani tambak di pesisir Kabupaten Demak," J. Dedicators Community, vol. 1, no. 2, pp. 103-113, 2017.

[22] Muarif, A. Damar, S. Hariyadi, D. Sutrisno, and M. Boer, "Pengembangan variabel-variabel indeks kepekaan ekologi (IKE) bagi pengendalian tumpahan minyak di ekosistem mangrove," $J$. Kelaut. Nas., vol. 11, no. 1, pp. 21-34, 2016.

[23] H. de Verdal et al., "Improving feed efficiency in fish using selective breeding: a review," Rev. Aquac., vol. 10, no. 4, pp. 833-851, 2018.

[24] C. E. Boyd, "Overview of aquaculture feeds: global impacts of ingredient use," in Feed and Feeding Practices in Aquaculture, Woodhead P., D. A. Davis, Ed. Cambridge: Elsevier Ltd, 2015, pp. 3-25.

[25] A. M. R. Hanief, Subandiyono, and Pinandoyo, "Pengaruh frekuensi pemberian pakan terhadap pertumbuhan dan kelulushidupan benih tawes (Puntius javanicus)," J. Aquac. Manag. Technol., vol. 3, no. 4, pp. 67-74, 2014.

[26] K. Haetami, "Konsumsi dan efisiensi pakan dari ikan jambal siam yang diberi pakan tingkat energi protein berbeda," J. Akuatika, vol. 3, no. 2, pp. 146-158, 2012.

[27] O. J. Eriegha and P. A. Ekokotu, "Factors affecting feed intake in cultured fish species: a review," Anim. Res. Int., vol. 14, no. 2, pp. 26972709, 2017

[28] M. Aalimahmoudi, A. Reyshahri, S. S. Bavarsad, and M. Maniat, "Effects of feeding frequency on growth, feed conversion ratio, survival rate and water quality of white leg shrimp (Litopenaeus 
vannamei, Boone, 1931)," Int. J. Fish. Aquat. Stud., vol. 4, no. 3, pp. 293-297, 2016.

[29] AFCD, Prevention and Treatment of Fish Diseases. Hongkong: AFDC: Agriculture, Fisheries, and Conservation Department, 2009.

[30] O. Mansour, M. Idris, N. M. Noor, M. S. B. Ruslan, and S. K. Das, "Effects of organic and commercial feed meals on water quality and growth of Barbonymus schwanenfeldii juvenile," AACL Bioflux, vol. 10, no. 5, pp. 1037-1048, 2017.

[31] A. Malik, "Pengaruh pemberian suplemen dan probiotik terhadap hasil panen bandeng ( Chanos chanos ) di wilayah Desa Kentong Kecamatan Glagah Kabupaten Lamongan," GROUPER J. Ilm. Perikan., vol. 1, no. 1, pp. 57-65, 2010.

[32] D. Chilmawati, F. Swastawati, I. Wijayanti, Ambaryanto, and B. Cahyono, "Penggunaan probiotik guna peningkatan pertumbuhan, efisiensi pakan, tingkat kelulushidupan dan nilai nutrisi Ikan Bandeng (Chanos chanos)," Indones. J. Fish. Sci. Technol., vol. 13, no. 2, pp. 119-125, 2018.

[33] J. P. Fry et al., "Environmental health impacts of feeding crops to farmed fish," Environ. Int., vol. 91, pp. 201-214, 2016.

[34] O. I. Lekang, "Feeding equipment," in Feed and Feeding Practices in Aquaculture, D. A. Davis, Ed. Cambridge: Elsevier, 2015, pp. 349-368.

[35] R. B. Hastuti and E. D. Hastuti, "Perubahan Pola Alometri Pertumbuhan Ikan Bandeng ( Chanos chanos ) yang dibudidayakan dalam Tambak Wanamina di Kota Semarang," in Prosiding Seminar Nasional from Basic Science to Comprehensive Education, 2016, pp. 16-18.

[36] A. M. Samosir, E. F. Prahastianto, and S. Hariyadi, "Keberadaan Mangrove dan Produksi Ikan di Desa Grinting, Kecamatan Bulakamba, Kabupaten Brebes.," J. Ilmu-ilmu Perair. dan Perikan. Indones., vol. 17, no. 1, pp. 261-270, 2011.

[37] M. D. Indrayanti, A. Fahrudin, and I. Setiobudiandi, "Penilaian Jasa Ekosistem Mangrove di Teluk Blanakan Kabupaten Subang," J. Ilmu Pertan. Indones., vol. 20, no. 2, pp. 91-96, 2015. 